\title{
A Comparitive Study of Adsorption Behaviour of a Dye Using Agro Wastes as Adsorbents
}

\author{
Jyoti Rana ${ }^{1,}$ Dr. Shakti Kumar ${ }^{2}$ \\ I (M.E $2^{\text {nd }}$ year Student, Civil Engg Department, PEC University of Technology, Chandigarh, India) \\ ${ }^{2}$ (Associate Professor, Civil Engg Department ,PEC University of Technology,Chandigarh,India)
}

\begin{abstract}
The use of cheap and eco-friendly adsorbents are studied as an alternative substitution of activated carbon for the removal of dyes from wastewater. Laboratory investigations were done to find the potential of Rice husk ash(RHA), Activated Rice Husk (ARH) and Azadirecta indica leaves (Neem) powder (NLP ) to remove methylene blue dye from aqueous solution. ARH was prepared from rice husk treated with nitric acid and RHA Prepared by heating in muff furnace at $300^{\circ} \mathrm{C}$. Neem leaves are sundried for few days and then dried at low temperature $\left(<105^{\circ} \mathrm{C}\right)$ for 24 hrs in hot air oven to remove moisture content. The effects of various experimental parameters, such as $\mathrm{pH}$, adsorbent dosage and contact time were investigated. Langmuir adsorption isotherm was applied and $R^{2}$ value was calculated which shows, Langmuir adsorption is a good fit for the experimental data. The result shows that the $85 \%$ colour removal efficiency can be achieved at the dose of $50 \mathrm{~g} / \mathrm{l}$ of ARH. $90 \%$ colour removal efficiency is achieved at the adsorbent dose of $40 \mathrm{~g} / \mathrm{l}$ of RHA. With increase in RHA dose the efficiency increased upto $96 \%$. $81 \%$ of colour removal efficiency is achieved with NLP.
\end{abstract}

Keywords: Rice husk, neem leaves, Activated rice husk, methylene blue, adsorption isotherm

\section{Introduction}

Dyes are highly colored polymers and low biodegradable in nature. Wastewater effluents from different industries such as textiles, rubber, paper and plastics, contain several kinds of synthetic dyestuffs [1] Dye being one of the important recalcitrant, persist for long distances in flowing water, retards photosynthetic activity, inhibit the growth of aquatic biota by blocking out the sunlight and utilizing dissolved oxygen and also decrease the recreation value of stream. Numerous studies have been conducted to assess the harmful impacts of colorants on the ecosystem. It was found that dyes may cause problems in water in several ways. Adsorption is quite popular due to simplicity and high efficiency, as well as the availability of a wide range of adsorbents. It has proved to be an effective method for removal of dye from wastewater [2], the most commonly used adsorbent for this purpose has been activated carbon but, due to the relatively high operating costs, this adsorbent had limited application on a larger scale. Recently, numerous approaches have been studied for the development of cheaper and effective adsorbents. The present research tends to investigate RHA,ARH and Neem (Azadirachta indica) leaves as a low-cost adsorbent for the removal of dyes from aqueous solutions.

\subsection{Material}

\section{Material And Methods}

Neem Leaves were collected and washed properly under rushing tap water to remove water-soluble impurities and then dried in a thermostatic oven at $105^{\circ} \mathrm{C}$ for 24 hours. After drying process, neem leaves were ground to fine powder and sieved through $600 \mu$ size. The adsorbent RHA was collected in the form of rice husk . Rice husk was collected from rice mill situated in Dharamshala H.P. Rice Husk was initially burnt in open in a vessel using burner and later heated in the muffle furnace at nearly $300^{\circ} \mathrm{C}$. For preparing $\mathrm{ARH}$ the rice husk was screened and washed with water to remove the dirt and was sun dried for a day. Then the dried rice husk was soaked in $2.0 \mathrm{~mol} / \mathrm{L}$ of nitric acid for an hour. It was then rinsed with distilled water for 2-3 times and oven dried at $105^{\circ} \mathrm{C}$ for 2 hours

The stock solution of dye was prepared by dissolving $1 \mathrm{~g}$ of methylene blue in $1000 \mathrm{ml}$ of distilled water. The working solutions were prepared by serial dilution of this stock solution. Dye concentration was determined by using absorbance values measured before and after the treatment, at $650 \mathrm{~nm}$ with Spectrometer. Experiments were carried out at initial $\mathrm{pH}$ value is 7.2 and was controlled by addition of sodium hydroxide and hydrochloric acid.

\subsection{Experimental Procedure}

The working solution of $10 \mathrm{mg} / 1$ was prepared by serial dilution of stock solution. The factors initial $\mathrm{pH}$, contact time and adsorbent dose were varied. The batch adsorption tests were carried out by shaking $50 \mathrm{ml}$ 
working dye solution in a conical flask. The conical flasks were placed on rotary shaking machine for the desired time at $150 \mathrm{rpm}$. The progress of adsorption during the experiment was determined by removing the flask after desired contact time, centrifuging and analyzing the supernatant solution spectrophotometrically at $650 \mathrm{~nm}$. The removal efficiency was calculated using

$$
\% \mathrm{Q}=\frac{(\mathrm{C} i-\mathrm{C} f)}{\mathrm{C} i} \times 100
$$

Where $\% Q=$ percentage of dye adsorbed, $C i=$ initial dye concentration $(\mathrm{mg} / \mathrm{lit})$ ad $\mathrm{C} f=$ final dye concentration (mg/lit) The Langmuir adsorption isotherms was tried to fit to the experimental adsorption data.

\subsection{Effect of $\mathrm{pH}$}

\section{Results And Discussions}

The dye -RHA interaction shows low adsorption rate at $\mathrm{pH} 2$. Between $\mathrm{pH}$ 3-8 adsorption increases from $60 \%$ to $95 \%$. At pH 9 the adsorption was $92 \%$ and at $11 \mathrm{pH}$ the adsorption was $85 \%$. The maximum adsorption capacity was found at $\mathrm{pH} 8$.So 8 is the optimum $\mathrm{pH}$. For the dye-ARH interaction between $\mathrm{pH}$ 3-8 adsorption increases from $60 \%$ to $85 \%$. At $\mathrm{pH} 7$ the adsorption was $84 \%$ and at $11 \mathrm{pH}$ the adsorption was $80 \%$. The maximum adsorption capacity was found at $\mathrm{pH}$ 7. For NLP below $\mathrm{pH} 6$ the solution becomes turbid and changes its colour. Therefore the study is conducted between 6-11pH only. At pH 6-8 adsorption increases from $60 \%$ to $75 \%$. At $\mathrm{pH} 8$ the adsorption was $75 \%$. The maximum adsorption capacity was found at $\mathrm{pH} 8$.

Fig.1 Effect of pH on adsoption using ARH
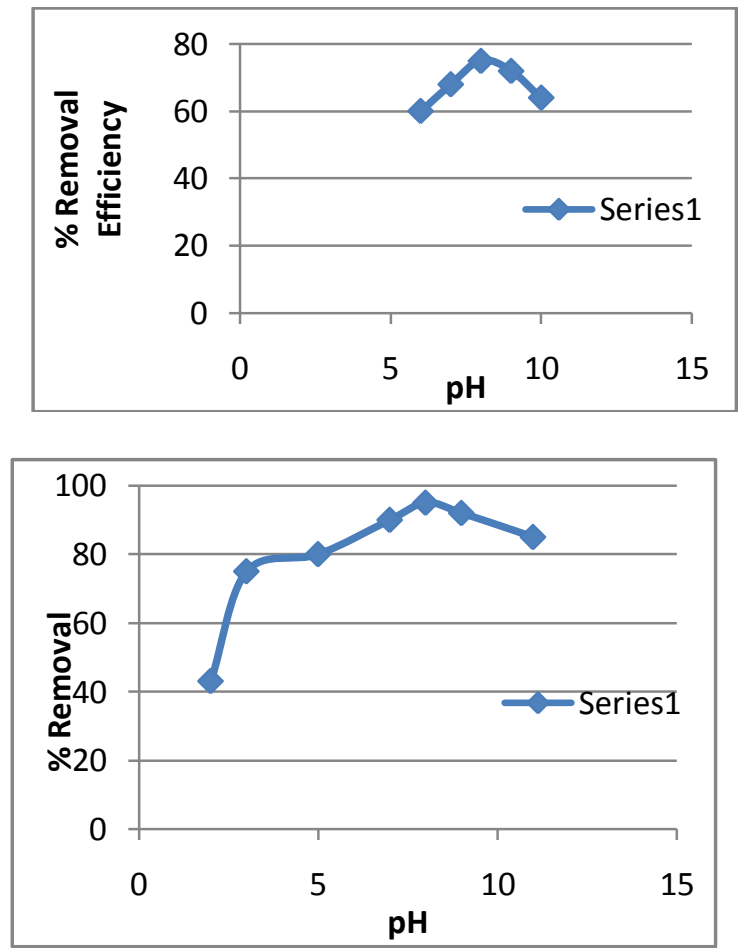

Fig. II: Effect of pH on adsorption using NLP
Table:I Effect of pH on adsoption using ARH

\begin{tabular}{|c|c|}
\hline $\mathbf{p H}$ & \% Removal \\
\hline 3 & 60 \\
\hline 4 & 70 \\
\hline 6 & 75 \\
\hline 7 & 84 \\
\hline 8 & 85 \\
\hline 10 & 80 \\
\hline
\end{tabular}

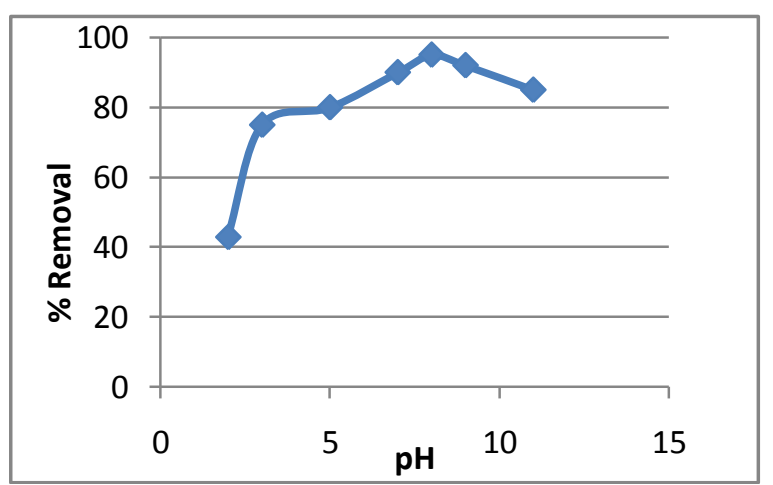

Fig.III:Effect of pH on adsoption using RHA

\subsection{Effect of contact time}

The effect of contact time on the amount of dye adsorbed was investigated at the $10 \mathrm{mg} / \mathrm{l}$ of dye concentration . For RHA the effect of contact time was investigated for 10,20,40,60,80,100 and 120 min at the $\mathrm{pH} 8$ and $2 \mathrm{gm} / 50 \mathrm{ml}$ of sample dosage. The extent of removal of Methylene Blue by Rice husk ash was found to increase with increase in contact time. Reach a maximum at a contact time of 60 minutes. For ARH the maximum adsorption was at a contact time of 80 minutes. Later it almost becomes constant with increase in contact time. The extent of removal of Methylene Blue by NLP was also found to increase with increase with contact time. It reaches a maximum at a contact time of 120 minutes. Later it starts decreasing. 
A Comparitive Study Of Adsorption Behaviour Of A Dye Using Agro Wastes As Adsorbents

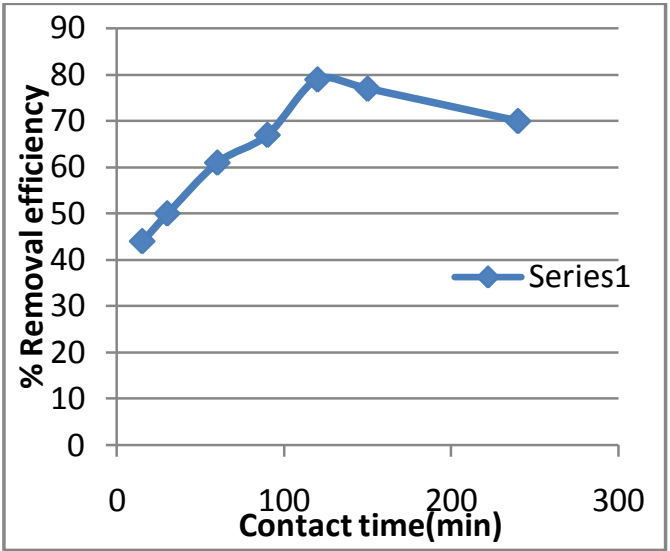

Fig.IV: Effect of time of contact using NLP as adsorbent

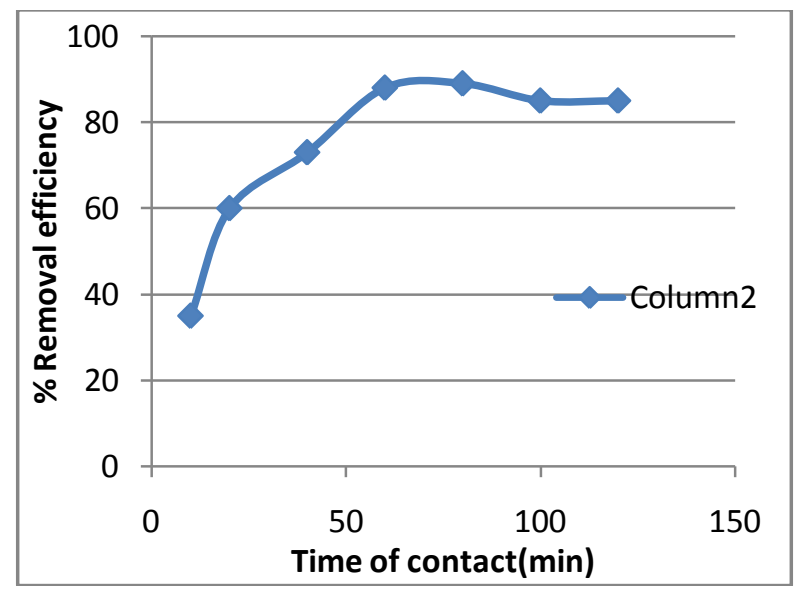

Fig.VI: Effect of time of contact using ARH as

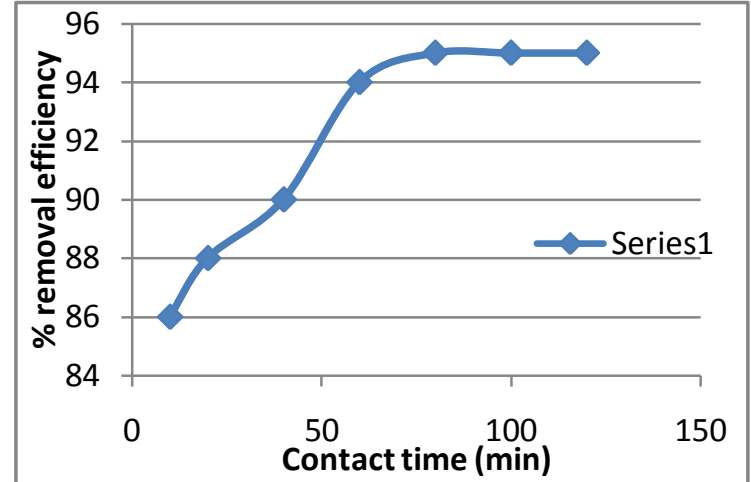

Fig.V: Effect of time of contact using RHA as adsorbent

Table:II Effect of time of contact for ARH

\begin{tabular}{|c|c|}
\hline Time of Contact & $\begin{array}{c}\text { \% Removal } \\
\text { efficiency }\end{array}$ \\
\hline 10 & 35 \\
\hline 20 & 60 \\
\hline 40 & 73 \\
\hline 60 & 88 \\
\hline 80 & 89 \\
\hline 100 & 85 \\
\hline 120 & 85 \\
\hline
\end{tabular}

\subsection{Effect of adsorbent dose}

The removal efficiency was $90 \%$ to $96 \%$ was observed at apH of 8 and contact times of $120 \mathrm{~min}$. The optimum dose is $2 \mathrm{~g} / 50 \mathrm{ml}$, at which $95 \%$ of removal efficiency is achieved. For ARH at a contact times and $\mathrm{pH}$ were $120 \mathrm{~min}$ and 7, respectively the removal efficiency was $67 \%$ to $80 \%$. The optimum dose is $2.5 \mathrm{~g} / 50 \mathrm{ml}$ at which $85 \%$ of removal efficiency is achieved. For NLP the removal efficiency was $30 \%$ to $82 \%$. The optimum dose is $5 \mathrm{~g} / 50 \mathrm{ml}$. At which $82 \%$ of removal efficiency is achieved.

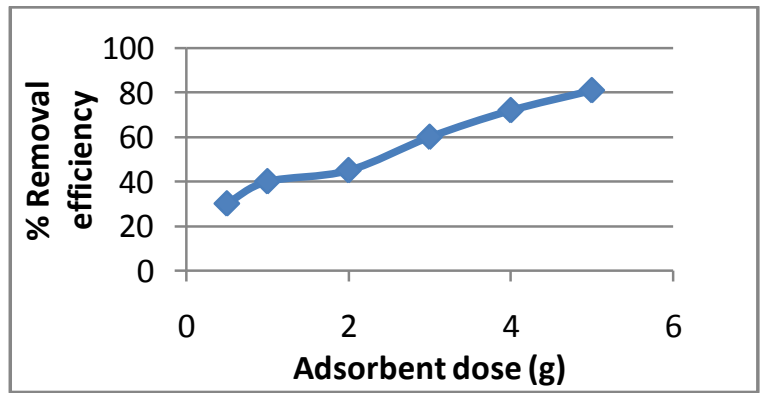

Fig.VII: Effect of NLP dose on adsorption

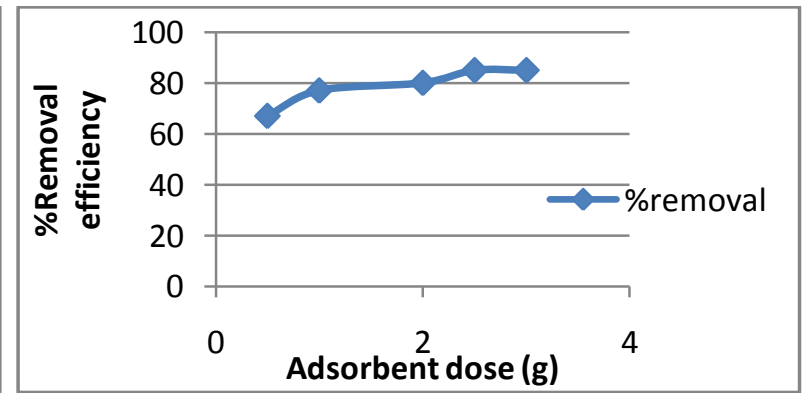

Fig.VIII: Effect of ARH dose on adsorption 
Table:III Effect of RHA dose on adsorption

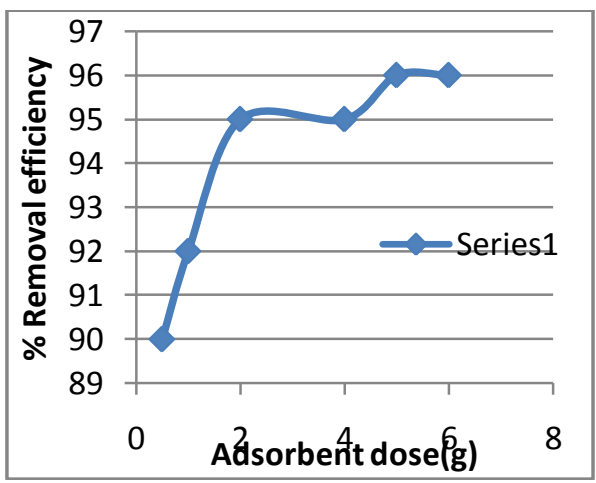

\begin{tabular}{|c|c|}
\hline $\begin{array}{c}\text { Adsorbent Dose } \\
\text { (g/50 ml) }\end{array}$ & $\begin{array}{c}\text { \% Removal } \\
\text { efficiency }\end{array}$ \\
\hline 0.5 & 90 \\
\hline 1 & 92 \\
\hline 2 & 95 \\
\hline 4 & 95 \\
\hline 5 & 96 \\
\hline
\end{tabular}

Fig: IX. Effect of RHA dose on adsorption

\subsection{Langmuir Adsorption Isotherm}

Langmuir adsorption isotherm graph is plotted with $l / q e \mathrm{v} / \mathrm{s} l / \mathrm{Ce}$. Trend line for the adsorption data of methylene blue using different adsorbents are plotted. The linear regression was conducted using plot $1 / \mathrm{qe} v / s$ $1 / \mathrm{Ce}$, it was found that $\mathrm{R}^{2}$ values are closer to 1 , indicating that the Langmuir adsorption isotherm is a good fit for all the adsorption data.

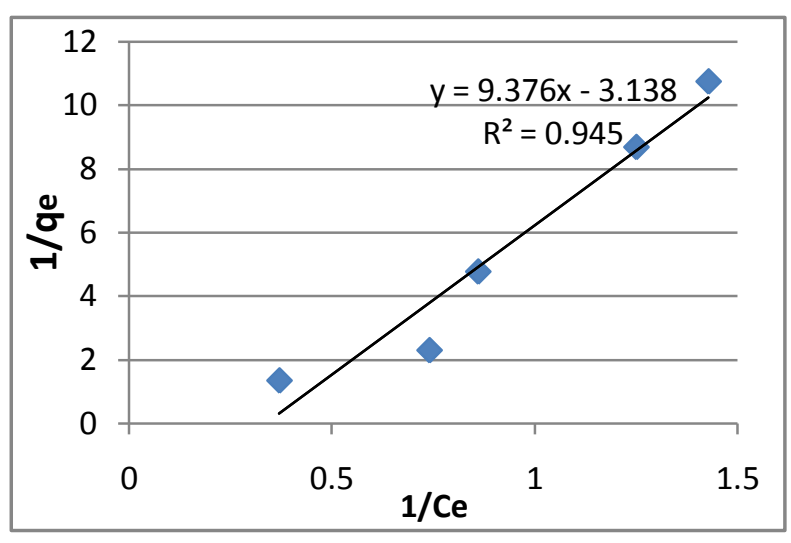

Fig.XI: Langmuir adsorption isotherm for RHA

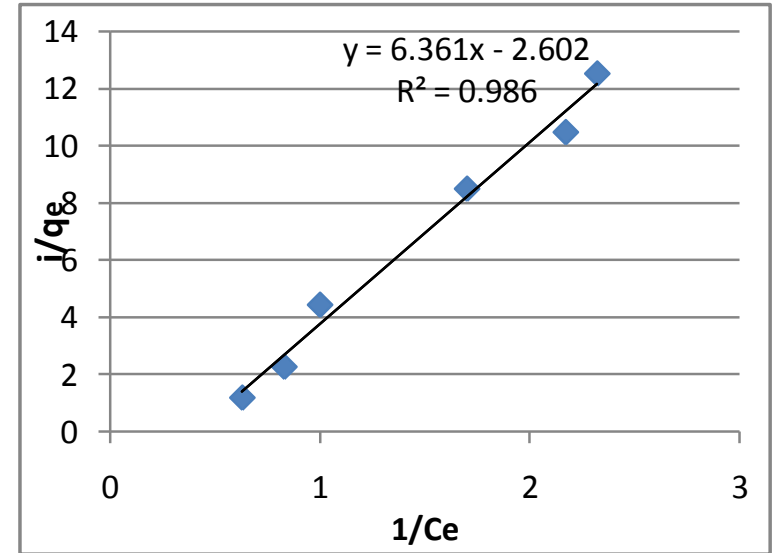

Fig.X:Langmuir adsorption isotherm for ARH

Table:3 Langmuir adsorption isotherm for ARH

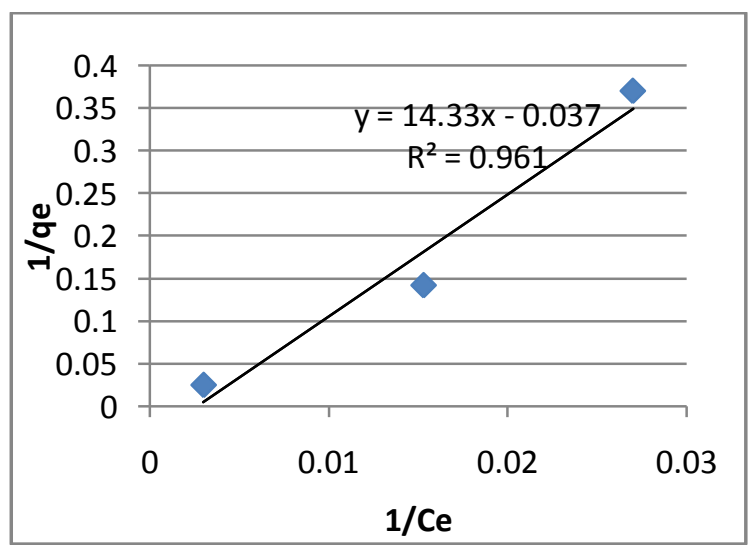

\begin{tabular}{|c|c|}
\hline $\mathbf{1 / C e}$ & $\mathbf{1 / q e}$ \\
\hline 0.37 & 1.36 \\
\hline 0.74 & 2.31 \\
\hline & \\
0.86 & 4.78 \\
\hline 1.25 & 8.69 \\
\hline 1.428 & 10.75 \\
\hline
\end{tabular}

Fig.XII: Langmuir adsorption isotherm for NLP 
Table: 4 Summary of Results obtained

\begin{tabular}{|l|c|c|c|c|c|c|}
\hline Sr. & $\begin{array}{c}\text { Name of the } \\
\text { Adsorbent }\end{array}$ & $\begin{array}{c}\text { Optimum } \\
\mathbf{p H}\end{array}$ & $\begin{array}{c}\text { Optimum Dose } \\
(\mathbf{g} / \mathbf{I})\end{array}$ & $\begin{array}{c}\text { Optimum } \\
\text { Contact } \\
\text { Time(Min) }\end{array}$ & $\begin{array}{c}\text { Maximum \% } \\
\text { Removal } \\
\text { Efficiency }\end{array}$ & $\begin{array}{c}\mathbf{R}^{2} \text { values } \\
\text { using } \\
\text { Langmuir } \\
\text { Isotherm }\end{array}$ \\
\hline $\mathbf{1}$ & RHA & 8 & 40 & 60 & 96 & 0.945 \\
\hline $\mathbf{2}$ & ARH & 7 & 50 & 80 & 89 & 0.986 \\
\hline $\mathbf{3}$ & NLP & 8 & 100 & 120 & 81 & 0.961 \\
\hline
\end{tabular}

\section{Conclusion}

The result of present study clearly shows that ARH, RHA and NLP are effective in removal of methylene blue and can provide an economical solution for removal of such colour from the aqueous solution.

a) For ARH $85 \%$ colour removal efficiency can be achieved at the dose of $50 \mathrm{~g} / \mathrm{l}$ at a contact time of $80 \mathrm{~min}$ on further increasing the contact time the $\%$ removal efficiency remains constant, The optimum $\mathrm{pH}$ obtained is 7.

b) For NLP $81 \%$ of colour removal efficiency is achieved at the dose of $100 \mathrm{~g} / \mathrm{l}$ at a contact time of 120 minutes at $\mathrm{pH}$ of 8 . Below $\mathrm{pH} 6$ the (NLP-dye) solution becomes turbid and changes its colour. Therefore the study is conducted between $6-11 \mathrm{pH}$ only

c) For RHA $96 \%$ colour removal efficiency is achieved at the adsorbent dose of $40 \mathrm{~g} / \mathrm{l}$ of at a contact time of 60 minutes The optimum $\mathrm{pH}$ obtained is 8 . Above and under this point, adsorption slightly tends to decrease. . RHA also shows good efficiency in less time than that of ARH and NLP. Less dose of RHA is required.

The Langmuir adsorption isotherms is applied. The result shows that the Rsquare values are closer to 1 for all adsorption isotherm plots. Thus Langmuir isotherm model is good fitted to the experimental data. Thus full utilization of agro-waste and treatment of wastewater is one of the good prospective for good environment. The ARH,RHA,NLP can be proved as good, effective and eco friendly adsorbent .Among these three RHA has maximum \% removal efficiency in less time and less dose then the other two.

\section{References}

[1] Chakraborty, S., Purkait, M.K., DasGupta, S., De, S., Basu, J.K., 2003. Nanofiltration of textile plant effluent for color removal and reduction in COD. Sep. Purif. Technol. 31 (2), 141-151

[2] Dany, C. K., Ch e u n g, C. W., Ch o y , K. K. H., Porter, J.F., McKay, G., 2004. Sorption equilibria of metal ions on bone char. Chemosphere 54, 273-281

[3] K.Hunger, Industrial dyes: chemistry, properties, applications, Wiley-VCH, Weinheim, Cambridge, (2003).

[4] K.Venkataraman, The chemistry of synthetic dyes, Academic press Inc., New York, (1965).

[5] B.Dash, Competitive adsorption of dyes (congo red, methylene blue, malachite green) on activated carbon, B.Tech thesis, 2010.

[6] G.Crini, Non-conventional low-cost adsorbents for dye removal: a review, Bioresour, Technol.97 (2006) 1061-1085.

[7] A. Mittal, A. Malviya, D. Kaur, J. Mittal, L. Kurup, Studies on the adsorption kinetics and isotherms for the removal and recovery of Methyl Orange from wastewaters using waste materials, J. Hazard, Mater. 148 (2007) 229-240.

[8] S. Chen, J. Zhang, C. Zhang, Q. Yue, Y. Li, C. Li, Equilibrium and kinetics studies of methyl orange and methyl violet adsorption on activated carbon derived from phragmitesaustralis, Desalination 252 (2010) 149-156.

[9] C.I.Pearce, J.R.Lloyd, J.T.Guthrie, The removal of colour from textile wastewater using whole bacteria cells: a review, Dyes pigments 58 (2003) 179-196.49

[10] T.Robinson, G.Mcmullan, R.Marchant, P.Nigam, Remedition of dyes in textile effluent: a critical review on current treatment technologies with a proposed alternatives, BioresourTechnol.77 (2001) 247-255.

[11] Y.Anjanyeulu, N.Sreedhara, D.Chary, Suman Raj Samuel, De-colourization of industrial effluents-available methods and emerging technologies- a review, Rev. Environ. Sci. Biotechnol.4 (2005) 245-273.

[12] H.SinghRai, M.S.Bhattacharyya, J.Singh, T.K.Bansal, P.Vats, U.C.Banerjee, Removal of dyes from the effluent of textile and dyestuff manufacturing industry: a review of emerging techniques with reference to biological treatment, Crit. Rev. Environ. Sci. Technol.35 (2005).

[12] G.Crini. P.M.Badot, N.M.Crini, G.Torri, Wastewater treatment processes: a recent review of the available methods, in: Press universitaires de Franche-Comte (PUFC), (2007) 16-62.

[14] F.Gimbert, N.M.Crini, F.Renault, P.M.Badot, G.Crini, Adsorption isotherm models for dye removal by cationized starch-based material in a single component system: error analysis, J. Hazard, Mater,157 (2008).

[15] M.Dogan, M.Alkan, Adsorption kinetics of methyl violet into perlite, Chemosphere 50 (2003).

[16] C.C.Wang, L.C.Juang, T.C.Hsu, C.K.Lee, J.F.Lee, F.C.Huang, Adsorption of basic dyes onto montmorillonite, J.ColloidInerface Sci. 273 (2004) 80-86. 